\title{
AZ AGRÁR- ÉS VIDÉKFEJLESZTÉSI TÁMOGATÁSOK MEGÍTÉLÉSE ÉS HATÁSA A DÉL- ALFÖLDI RÉGIÓBAN
}

\section{ASSESSMENT AND IMPACT OF AGRICULTURAL AND RURAL DEVELOPMENT SUBSIDIES IN THE SOUTHERN PLAIN REGION}

Horváth Péter ${ }^{1}$

${ }^{1}$ Vidékfejlesztési és Regionális Gazdaságtan Tanszék, Gazdaságtudományi Kar, Debreceni Egyetem

\author{
Kulcsszavak: \\ EU támogatás \\ mezőgazdasái támogatás \\ vidékfejlesztési támogatás \\ Dél-alföldi Régió \\ megítélés \\ Keywords: \\ EU subsidy \\ agriculture subsidy \\ rural development subsidy \\ Southern Great Plain Region \\ assessment
}

\section{Összefoglalás}

Az európai uniós csatlakozás révén hazánk számos támogatási csatornán keresztül juthatott forráshoz. A hazai gazdálkodók az EU közös agrár-és vidékfejlesztési politikája révén szintén jelentős támogatási forrásból részesülhetnek. A támogatások objektív és szubjektív megítélése heterogén módon alakul hazánkban. A tanulmány a Dél-alföldi Régió egyik járásán keresztül mutatja be a támogatások megítélésének föbb szempontjait, továbbá arra keresi a választ, hogy milyen objektív és szubjektív tényezők hathatnak a támogatások megítélésére.

\section{Abstract}

The change of The change of regime resulted in significant changes in the life of the Hungarian rural areas; while the rural income of Hungary used to be world-class, after the change of regime it became incredibly low. Accession to the European Union and the European rural policy opened new aspects for rural areas and the people living there. The study presents the sociodemographic and farming characteristics of families receiving $E U$ subsidies in the Southern Great Plain Region 15 years after the EU accession.

\section{Bevezetés}

2001-ben a Göteborgi csúcstalálkozó eredményeképpen megszületett Magyarország európai uniós csatlakozásának céldátuma, amelynek révén 2004-től EU tagállammá vált hazánk. Az uniós csatlakozás azonban nem hozta el a várva várt hatást, hiszen a csatlakozó tíz ország közül pozíció vesztesként, sereghajtóként léphettünk be a Közösségbe. A gazdasági egyensúlyra és versenyképességre vonatkozó mutatók árnyalt képet mutattak [2]. Más szerző́k

${ }_{1}$ Kapcsolattartó szerző. Tel.: +36 52508444

E-mail cím: horvath.peter@econ.unideb.hu 
szintén megállapítják, hogy nem történtek alapvető változások a magyar agrárgazdaságban a csatlakozás után, bizonyos mutatók tekintetében romlott a helyzet, úgymint a foglalkoztatottság, bruttó hozzáadott érték előallítás, beruházások mezőgazdasági részaránya [3].

A csatlakozást követően a magyar mezőgazdaság a Közös Agrárpolitika szabályozása alá került számos tekintetben. Közösségi szinten deklarálták a támogatott termékeket és tevékenységeket, az élelmiszerbiztonsági, állat- és növény-egészségügyi követelményeket, valamint termelési és támogatási kvóták kerültek kialakításra, hogy ellenőrizhető keretben tartsák a támogatott termelést. A vidékfejlesztési programok kialakításában már nagyobb önállóságot kaptak az újonnan csatlakozottak. Közvetlen támogatások tekintetében az alacsonyabb költségszintre, és a költségvetési hiányra hivatkozva kezdetben a tagállami támogatások 20\%-át kapták a hazai gazdálkodók, amelyet nemzeti forrásból kiegészíthetett az ország [4].

A Közös Agrárpolitika révén négy támogatási csatorna állt hazánk rendelkezésére: a közvetlen támogatások, a piacstabilizáló intervenciós és exporttámogatások, a vidékfejlesztési, környezetvédelmi, beruházási, illetve a szerkezetátalakításért felelős támogatások, valamint negyedikként a nemzeti támogatások. Az egyes EU-s forrásokhoz hozzá lehet jutni normatív úton, amiről jogszabály rendelkezik, míg más alapok egyedi kérelem útján vehetők igénybe, illetve a forráshoz jutás harmadik útja a klasszikus pályázati rendszer, amelynek a feltételeit a pályázati felhívás rögzíti [10].

A közvetlen támogatások kifizetése esetében Magyarország egy területalapú rendszer mellett döntött (Single Area Payment Scheme - SAPS - Egységes Területalapú Támogatás). A csatlakozás óta a közvetlen támogatások évről évre nőttek és 2013-ra érték el a régi tagállamok támogatottsági szintjét, 2010-tôl a nemzeti kiegészítés révén (top up - kipótlás) a támogatások kiegyenlítődtek [9]. Ez viszont egy ellentmondásos forma, hiszen a SAPS egy termeléstől elválasztott támogatás, és az ehhez kapcsolódó top up viszont termeléshez kötött, azon növénykultúrák részesülnek kiegészítő támogatásban, amelyek az EU-15-ök esetében is részesei [8].

A Közös Agrárpolitika (KAP) reformja következtében 2015-től jelentősen átalakult a közvetlen támogatások rendszere. A változások eredményeképpen a legújabb kihívásokra kiemelten reagáló, környezettudatosabb, és ennek következtében több új jogcímet felölelő rendszer jött létre. A KAP-pal szembeni új kihívások, mint a csökkenő biodiverzitás, a környezetvédelem, az egyre kisebb létszámú és elöregedő gazdatársadalom mind-mind szükségessé tették a rendszer átalakítását, az európai uniós agrárpolitika változó környezethez történő adaptációját [6].

A 2014-2020 közötti európai uniós költségvetési ciklusban az Európai Unió elfogadott teljes költségvetése 960 milliárd euró, ami 3,4\%-kal alacsonyabb, mint a megelőző periódusban. A KAP részesedése a teljes keretből 38,9\%, 373 milliárd euró. Ez 3,5 százalékponttal alacsonyabb, mint a 2007-2013 közötti pénzügyi időszakban. Az EU költségvetésének mintegy 38\%-át teszi ki a KAP pénzügyi kerete, ami az EU GDP-jének 0,4\%a. Elmondható, hogy az Európai Unió Közös Agrárpolitikája, a csökkenő költségvetés ellenére is az EU legnagyobb költségvetéssel múködő közösségi politikája. Bár - elsősorban a nettó befizető országok részéről erős támadások érik magas költségvetését, amelyek a KAP büdzsé egyre csökkenő mértékét is eredményezik, mégis a KAP az Európai Unió legrégebbi és legsikeresebb politikája, amely kétségkívül a 2020 utáni időszakban is megőrzi méltó helyét [6].

\section{A kutatás módszertana}

A tanulmány egy 2019-es kérdőíves felmérés eredményeire épül, amelynek részeredményei már kerültek publikálásra [1], így a kutatás részleteinek a leírása hasonlóképpen alakul. A „face to face” (személyes) zárt és nyitott kérdéseket is tartalmazó kérdőíves interjúkon alapuló felmérés egy konkrét dél-alföldi járás szintjén vizsgálta az agrárés vidékfejlesztési támogatások megítélését és hatását, de a levonható tanulságok akár országos szinten is jellemzőek lehetnek. 
A kutatás helyszínéül szolgáló dél-alföldi járás 11 településnek mindegyikéről rendelkezésemre állt a Magyar Âllamkincstár 2018. évi közzétételi listája, ahonnan a támogatási adatok leszűrhetôk. Ez alapján 1.080 családot érintettek a támogatások, amely azért hangsúlyos, mert az adatbázisban azonos lakcím alatt több név is szerepelt, illetve voltak olyan nevek, amelyek az adatsorban többször ismétlődtek (azaz többféle támogatást vettek igénybe). A nevek és a lakcímek ismétlődéseinek a kiszűrése után került sor az adatfelvétel lebonyolítására, egyszerü véletlen (valószínűségi) mintavételi technika alkalmazásával. Az alapsokaságból végül 293 válaszadó került a mintába, ami 27 százalékos mintavételezést jelent. A maximális becslési bizonytalanság így kisebb, mint 5\%. A válaszok elemzése során feltárt szignifikáns belső összefüggések szinte bizonyosan általánosan is érvényesek, még akkor is, ha az alapbecsléseknél könnyen elképzelhető, hogy ezek eloszlása eltérő lehet földrajzilag. Éppen ezért, ahol csak lehetett és értelmes is volt, igyekeztem ezeket a belső összefüggéseket feltárni.

A 293 fős mintába belekerült 3 nagygazdaság is, melyekben 23 főnél több embert foglalkoztatnak és nagyon sok állatott tartanak, illetve nagyon nagy területen folytatnak növénytermesztést. E gazdaságok jellemzői természetesen nagyon megnövelik a válaszok szórását, és így csökkentik a becslések megbízhatóságát. Ezért úgy döntöttem, hogy ezt a 3 nagyvállalkozást kihagyom az adatok elemzéséból, így a kutatás esetszáma: N=290 mikro-, kisés közepes mezőgazdasági gazdálkodó [1].

A támogatási rendszer szubjektív megítélésének az elemzésére faktorelemzés került alkalmazásra. Több szerző munkája alapján a módszer a változók közötti kapcsolatrendszer feltárása, illetve a változók számának a csökkentése révén lényegesen megkönnyíti az adatok elemzését és definiálását. Az eljárás a struktúra-feltáró módszerek közé sorolható, hiszen nincsenek előre meghatározott függő és független változók, hanem a különböző változók közötti összefüggések kiderítése a cél [7][5]. Ez egy kölcsönös összefüggésen alapuló módszer, ahol a kapcsolatok egésze kerül vizsgálásra [5].

\section{A támogatások megítélése}

A mintavétel módjából adódóan a vizsgált gazdaságok mindegyike kap valamilyen földalapú agrártámogatást. Egységes területalapú támogatásban a felkeresett gazdálkodók 98 százaléka részesül, valamilyen más jellegü támogatásban (is) pedig 6 százalékuk. A földalapú támogatásoknak, tehát nagyon jelentős szerep jut a vizsgált járás gazdálkodóinak megélhetésében.

A felkeresett gazdaságok 92 százaléka nem csak földalapú, hanem valamilyen állattartással kapcsolatos állatszám alapú támogatásban is részesül, azaz a térségben a földet is művelő és állatokat is tartó gazdálkodás tekinthető általánosnak, és alig van olyan gazdaság, ami 1-2 növény termesztésére, illetve állattartásra specializálódott volna.

A megítélés feltárása kapcsán fontos bemutatni egy korábbi kutatás eredményét, amely fontos előzménye a mostani munkának [1]. A mezőgazdasági tevékenységből származó jövedelem százalékos aránya azoknál a családoknál a legmagasabb, akik gazdaság bővítési terveik vannak, míg az egységes földalapú támogatásokból származó bevétel százalékos aránya a mezőgazdaságból származó jövedelmek megoszlásában azok körében magas, akik csökkenteni tervezik a gazdaságukat. Az egységes földalapú támogatás, tehát enyhíti a kedvezőtlenebb körülmények között élő családok helyzetét, de nem igazán ösztönöz a mezőgazdasági tevékenység bővítésére. A mezőgazdasági termelést elsősorban azok tervezik bővíteni, akiknél eredményes ez a tevékenység, és így az átlagosnál kisebb jelentősége van a számukra a földalapú támogatásnak (hipotézis-vizsgálat 1 szempontos variancia-analízissel (ANOVA): $\mathrm{F}=7,71 \mathrm{df}=2$ és 285, $\mathrm{p}=0,001$ illetve $\mathrm{F}=8,69, \mathrm{df}=2$ és 285, $\mathrm{p}=0,0005$. Független változók: 1. a mezőgazdasági tevékenységből származó jövedelmek százalékos aránya az összes gazdaságból származó jövedelmen belül, 2. a földalapú támogatásból származó bevétel százalékos aránya a az összes gazdaságból származó jövedelmen belül) (1. ábra). 


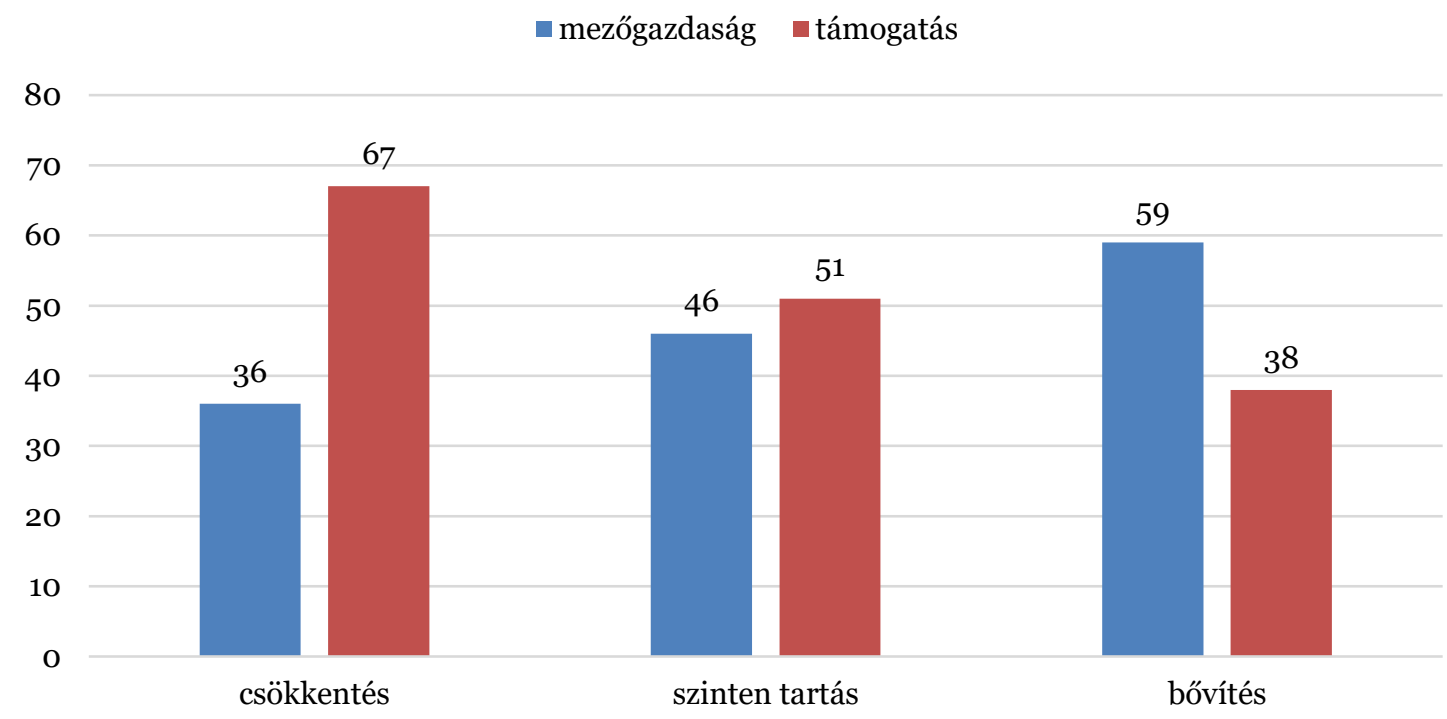

1. ábra: A mezőgazdasági tevékenységből, illetve az egységes földalapó támogatásból származó bevételek százalékos arányai, gazdasággal kapcsolatos tervek szerint Forrás: saját kutatás

A támogatások objektív hatása, tehát a vizsgált járásban tehát nem tekinthető gazdaság ösztönzőnek. Ugyanakkor a támogatásokkal kapcsolatos állítások megítéléseit nézve kissé más a kép. Arra kértem a válaszadókat, hogy mondják meg mennyire értenek egyet 7 állítással. A válaszokat a további elemzések egyszerüsítése és a szemléletesség érdekében úgynevezett mérleg-indexre vetítettem: egyáltalán nem ért egyet $=-100$ pont, nem ért egyet $=-50$ pont, egyet is ért meg nem is $=0$ pont, egyetért $=+50$ pont, teljes mértékben egyetért $=+100$ pont. $\mathrm{Az}$ eredményeket ismertető 1 . táblázatban az elutasítók százalékos arányát, a válaszok mérlegét (átlag), és az egyetértők arányát adtam meg.

Négy állítás esetében pozitív a válaszok mérlege, azaz ezek az állítások több egyetértésre, mint elutasításra találtak. Három állításnál viszont negatív a mérleg.

1. táblázat: A területalapú támogatás megítélése

\begin{tabular}{|c|c|c|c|}
\hline százalékok és átlag, $N=290$ & $\begin{array}{l}\text { nem ért } \\
\text { egyet }\end{array}$ & mérleg & egyetért \\
\hline $\begin{array}{l}\text { A kifizetések gyorsan és pontosan érkeznek a } \\
\text { gazdálkodókhoz. }\end{array}$ & $10 \%$ & +39 pont & $70 \%$ \\
\hline Egyszerü adminisztráció. & $23 \%$ & +19 pont & $59 \%$ \\
\hline $\begin{array}{l}\text { A SAPS támogatás érdekelté tette a gazdákat a } \\
\text { földterületük növelésében. }\end{array}$ & $20 \%$ & +26 pont & $59 \%$ \\
\hline $\begin{array}{l}\text { A támogatási rendszernek köszönhetően felfelé kezdett } \\
\text { ívelni a szántóföldi növénytermesztő ágazat. }\end{array}$ & $23 \%$ & +14 pont & $43 \%$ \\
\hline Javult a versenyképesség. & $42 \%$ & -5 pont & $31 \%$ \\
\hline Növekednek a mezőgazdasági jövedelmek. & $43 \%$ & -5 pont & 30\% \\
\hline $\begin{array}{l}\text { Ưj sikerágazatok térhódítását eredményezte pl.: } \\
\text { bioüzemanyag termelés. }\end{array}$ & $55 \%$ & -20 pont & $\mathbf{2 2 \%}$ \\
\hline
\end{tabular}

Forrás: saját kutatás

Első ránézésre, tehát azt találtuk, hogy az érintett gazdálkodók alapvetően elégedettek a támogatás folyósítás gyakorlatával. Ugyanakkor a szubjektív véleményeket nézve azt is, hogy a gazdák hajlamosak gazdaságélénkítő hatást is tulajdonítani a támogatásoknak. A modernizációs hatás, a jövedelemtermelő képesség és a versenyképesség tekintetében viszont több a szkeptikus vélemény, mint az egyetértés. 
Faktoranalízis ${ }^{2}$ segítségével egyszerre nézve a 7 választ, azt találtam, hogy ezek 2 faktorba rendeződnek. Az 1. faktor alapján képzett skála azt méri, hogy a válaszadók miként ítélik meg a területalapú támogatás gazdasági hatását, míg a 2. skála azt, hogy miként ítélik meg a támogatási rendszer múködési gyakorlatát. A faktorok alapján képzett skálákat a szemléletesség érdekében az alapválaszokhoz hasonlóan -100 és +100 pont közé kalibráltam. A faktor struktúrát ismertető 2. táblázatban a faktor súly azt mutatja, hogy az egyes állítások mennyire szorosan korrelálnak a faktorral, a faktorok alapján képzett skálák pedig valójában a faktorban számottevő súlyt kapó válaszok súlyozott átlagai.

A két faktor $\mathrm{r}=0,36(\mathrm{p}<0,0001)$ szinten, tehát nagyon erősen szignifikánsan, de távolról se függvényszerúen szorosan korrelál egymással. Ez azt jelenti, hogy a válaszokat az az általános attitűd is alakítja, hogy kinek mennyire szimpatikus maga a támogatási rendszer.

$\mathrm{Az}$ 1. faktorskála átlaga +1 pontnak adódott, azaz o pont közelében van a középérték. A skála értéke a válaszadók 41 százaléka körében egyértelműen negatív, 20 százalékuk körében o közeli, 39 százalékuk körében pedig egyértelmúen pozitív.

A 2. faktorskála átlaga +21 pont, azaz határozottan pozitív. A válaszadók 17 százaléka körében azonban negatív a skálaérték, 14 százalékuk körében pedig o pont közeli. A skálaértékek 69 százalékos többsége viszont egyértelműen pozitív, azaz a vizsgált járás támogatásban részesült gazdálkodóinak több, mint kétharmada, alapvetően elégedett a támogatásrendszer „bürokráciájával”.

2. táblázat: A támogatás rendszer szubjektív megítélésének faktorai (struktúra mátrix)

\begin{tabular}{|l|c|c|}
\hline \multicolumn{1}{|c|}{ faktor súlyok, $N=29 O$} & $\begin{array}{c}\text { gazdasági } \\
\text { hatás }\end{array}$ & bürokrácia \\
\hline A kifizetések gyorsan és pontosan érkeznek a gazdálkodókhoz. & & $\mathbf{0 , 8 1}$ \\
\hline Egyszerú adminisztráció. & $\mathbf{0 , 8 7}$ & $\mathbf{0 , 8 0}$ \\
\hline Javult a versenyképesség. & $\mathbf{0 , 8 6}$ & \\
\hline Növekednek a mezógazdasági jövedelmek. & $\mathbf{0 , 8 1}$ & \\
\hline $\begin{array}{l}\text { A támogatási rendszernek köszönhetóen felfelé kezdett ívelni a } \\
\text { szántóföldi növénytermesztő ágazat. }\end{array}$ & $\mathbf{0 , 6 5}$ & \\
\hline $\begin{array}{l}\text { Új sikerágazatok térhódítását eredményezte pl.: bioüzemanyag } \\
\text { termelés. }\end{array}$ & $\mathbf{0 , 6 3}$ & \\
\hline $\begin{array}{l}\text { A SAPS támogatás érdekelté tette a gazdákat a földterületük } \\
\text { növelésében. }\end{array}$ & \\
\hline
\end{tabular}

Forrás: saját kutatás

A gazdasági hatások faktorskála $\mathrm{r}=0,27 \quad(\mathrm{p}<0,001)$ szinten korrelál a válaszadó családjának havi jövedelmével és $\mathrm{r}=0,19(\mathrm{p}=0,001)$ szinten a válaszadók iskolázottságával, azaz az iskolázottabb, módosabb agrárvállalkozók az átlagosnál valamivel hajlamosabbak pozitívan vélekedni a földalapú támogatási rendszer gazdasági hatásairól. Ugyanakkor a múvelt terület nagyságával csak $\mathrm{r}=0,14(\mathrm{p}=0,015)$ az együtt változás szorossága, tehát nem igazán arról szól az ismertetett hatás, hogy ki mennyi támogatást kap. Sót a földalapú támogatások mezőgazdaságból származó jövedelmeken belüli százalékos aránya $\mathrm{r}=-0,25(\mathrm{p}<0,001)$ szinten, tehát nagyon erősen szignifikánsan negatívan korrelál a skálaértékkel. Tehát minél nagyobb a súlya a család megélhetésében a támogatásnak, annál hajlamosabb szkeptikusan vélekedni a támogatás gazdasági hatásairól.

A mezőgazdasági tevékenységből származó bevételek aránya viszont $r=0,24(p<0,001)$ szinten, azaz nagyon erősen szignifikánsan pozitívan korrelál a skálaértékkel. Ez egyfelől az jelenti, hogy a sikeresebb gazdálkodók hajlanak pozitívabban értékelni a támogatás gazdasági hatásait, másfelöl pedig azt, hogy a szubjektív véleményekre nagyjából ugyanúgy hatnak a külső tényezők, mint ahogy azt az objektív hatásnál is láttunk. Mindennek, tehát a mezőgazdasági tevékenység sikerességének és a véleményeknek is a hátterében az iskolázottság áll. A tanultabb gazdák sikeresebben gazdálkodnak és jobb a véleményük a

${ }^{2}$ Fő-komponens analízis, direkt oblimin rotáció. Utóbbi azt is jelenti, hogy megengedtük azt, hogy a faktorok korreláljanak egymással. A 2 faktor lefedi a teljes variancia 62 százalékát. 
földalapú támogatások gazdasági hatásairól. Ez viszont az is sejteti, hogy a legkevésbé tanult és ezzel párhuzamosan szegény válaszadók inkább csak felélik a támogatást, míg tanult gazdák beleforgatják a támogatásokat a gazdaságukba és nyilvánvalóan ettől (is) sikeresebbek. A bürokrácia megítélését mérő faktor esetében nem találtunk ilyen összefüggéseket.

\section{4. Összefoglalás}

Összefoglalásképpen megállapítható, hogy a támogatások objektív hatása a vizsgált járásban nem tekinthető gazdaság ösztönzőnek. A gazdálkodók alapvetően elégedettek a támogatás folyósítás gyakorlatával, ugyanakkor a szubjektív véleményeket nézve a gazdák hajlamosak gazdaságélénkítő hatást is tulajdonítani a támogatásoknak.

A modernizációs hatás, a jövedelemtermelő képesség és a versenyképesség tekintetében viszont több a szkeptikus vélemény, mint az egyetértés. Az általános attitűd is alakítja, hogy kinek mennyire szimpatikus maga a támogatási rendszer. Az iskolázottabb, módosabb agrárvállalkozók az átlagosnál valamivel hajlamosabbak pozitívan értékelni a földalapú támogatási rendszer gazdasági hatásait. De minél nagyobb a súlya a család megélhetésében a támogatásnak, a gazdálkodó annál hajlamosabb szkeptikusan vélekedni a támogatás gazdasági hatásairól.

Megállapítható, tehát, hogy mindennek: a mezőgazdasági tevékenység sikerességének és a véleményeknek is a hátterében az iskolázottság áll. A tanultabb gazdák sikeresebben gazdálkodnak és jobb a véleményük a földalapú támogatások gazdasági hatásairól.

\section{Irodalomjegyzék}

[1] Horvath, P. (2020): Az agrár- és vidékfejlesztési támogatásban részesülő családok szociodemográfiai és gazdálkodási sajátosságai egy dél-alföldi példán keresztül. Economica XI. Új évf., 12. Sz. (2020) ISSN 25602322

[2] Hubai, J. (2006): Az uniós csatlakozás hatása Magyarország természetierőforrás-gazdálkodására. Nemzeti Tankönyvkiadó. Budapest. 176.

[3] Kapronczai, I. - Udovecz, G. (2009): A magyar agrárgazdaság helyzete. Gazdálkodás. 53. 6. 532-545.

[4] Losoncz, M. (2004): Európai Uniós kihívások és magyar válaszok. Osiris Kiadó. Budapest. 274.

[5] Malhotra, N. K. (2009): Marketingkutatás, Akadémiai Kiadó Zrt., ISBN 9789630586481, Budapest, 832.

[6] NAK (2016): A közvetlen támogatások - gazdálkodói kézikönyv, https://www.nak.hu/kiadvanyok/kiadvanyok/576-kozvetlen-tamogatasok-kezikonyv/file

[7] Sajtos, L. - Mitev, A. (2007): SPSS kutatási és adatelemzési kézikönyv, Alinea Kiadó, Budapest, 402.

[8] Udovecz, G. (2007): Az európai agrárpolitika eszményei és realitásai. Gazdálkodás. 51. 2. 1-9.

[9] ÚMVP (2007): Új Magyarország Vidékfejlesztési Program. http://www.umvp.eu/files/umvp_program_teljes.pdf letöltés dátuma: 2012. január 11.

[10] Vásáry, M. (2008): Az agrártámogatási rendszer adaptációja (A közvetlen támogatások implementációjának egyes összefüggései). Doktori (PhD) értekezés. Szent István Egyetem. Gödöllő. 183. 